\title{
Research Promotion for Sustainable Health Development
}

Md. Nurul Amin 1

Research is a prerequisite for any field of scientific and social development. So is applicable for Medical Science. The central role of health research in improving health and stimulating national economic growth is now well-established. Health research supports and strengthens the health systems, in the delivery of better and more rational health care to people. It does so by identifying felt-need of the people and providing best solutions to them, and monitoring how health systems perform and how it should perform. It produces new knowledge, technologies and improved approaches to public health. The World Health Organization (WHO) has, time and again, affirmed that all national and international health policies should be based on valid scientific evidence, the evidence that derives from scientific reasoning and logical propositions. The application of such knowledge, information and technology that emanates from health research has enormous potential in promoting health, preventing disease, disability and death ${ }^{1}$

Shifting epidemiological trend in disease patterns, rapid increase in populations, emerging and reemerging health problems, increasing commercial interests of private health sectors and ever shrinking public health resources all contribute to global inequity in health care. It is, therefore, extremely important to identify the priorities in health sector so that national and international development partners can focus on the most important health issues and determinants of health. For this to happen, our health systems should have to be capable enough to provide convincing data resulting from research activities to justify allocation of the scarce resources ${ }^{1}$.

\section{Author's information:}

${ }^{1}$ Dr. Md. Nurul Amin, Assistant Professor, Department of Community Medicine, Rajshahi Medical College, Rajshahi \& Executive Editor, Ibrahim Cardiac Medical Journal, Ibrahim Cardiac Hospital \& Research Institute, Shahbag, Dhaka.
Health research is no luxury. The unprecedented health gains in the last century are undoubtedly the fruits of research. Conception prevails that health research should be conducted only by countries with resources to spare. When India gained independence, the country faced the problem of how to allocate its scarce resources to areas of most need. Pandit JawaharLal Nehru, in this context, made the following statement: "We cannot afford not to do research". The participation and contribution of developing countries in scientific research has been well-expressed by Pakistani Nobel Laureate Abdul Salam, as follows: "Science and Technology are shared heritage of all mankind; East and West, South and North have equally participated in their creation in the past, as we hope, they will in the future-the joint endevour in science is becoming one of the unifying forces among the diverse people of the globe².

In recent years, the United Nations are trying consistently to make the world a better place for people to live including the destitute and the rich. In pursuance of this, the United Nations had put various polices in place aiming at achieving the set goals. In the documentations of several world renowned investigators ${ }^{3,4}$ and the UNDP5, it was recorded that owing to the ravaging challenges faced by a lot of people across the globe, ranging from rampant epileptic lifestyle of the people to poverty, gender segregation and dichotomy, ecosystem depletion, and the likes, all development efforts are nipped in the bud. This led to the conglomeration of leaders from 189 countries in a meeting that held in the UN headquarters in New York in September 2000. The resolution of the meeting birthed the popularly known MDG 
(Millennium Development Goals). ${ }^{6}$ This was meant to address the development bottlenecks round the various nations of the world. Upon the review of the MDGs made by the United Nation in 2015, several shortcomings were discovered pertaining to the effectiveness of the MDGs. This review eventually birthed the currently known SDGs (Sustainable Development Goals). Although the millennium goals that were way back established had some level of achievement, but not withstanding. The sustainable development goals were initiated to improve on the deficiencies of Millennium goals implemented thus far, covering 17 core necessities for living that spans through quality research to environmental sustainability. ${ }^{7}$

Since the launching of sustainable development goals of the United Nations, it targeted towards making the world a very conducive and suitable place for humanity to stay in. This means that the seventeen (17) SDGs were born out of a passion to solve the generic problems of humanity. Hence, the role of research becomes extremely germane to positively catalyzing the processes and procedure required to attain the reality of it. The SDGs talks about the level of poverty, the standard of living the people, the ecosystem all have immense impact on health of the people. All of these are the make ups of the human survival mission. So, the role of research in the attainment of the SDGs should be the primary focus. ${ }^{8}$ As health development is one of the 17 goals of SDGs, health professionals cannot keep themselves away from research to make sustainable health development.

Considered in above context, all health professionals should have some know-how about research, or should have at least a level of research knowledge that will help them understand the published researches/studies. Even if they wish to spend their professional lives dealing with patients or health administration, a scientific approach is essential. As the practice of medicine is advancing rapidly, the need for critical evaluation of new developments is a must. The medical past is littered with examples of possible major advances eventually being shown to be of no value, or even to be harmful. Research helps to develop a scientific critical attitude in the evaluation of what is right and what is wrong ${ }^{1}$. Health policy-makers, particularly in developing countries may not appreciate the contribution, which research can make. There is still a division between the domain of research and domain of policy-making. The stereo type of the researchers in their 'ivory tower' still persists. In fact, health managers and policy-makers may be doing research without knowing it.

Thus, it appears that research paves the way of development. Accordingly, our Tertiary Medical Institutes should have been equipped with research 'know-how' and 'expertise'. But unfortunately, there are dearth shortages of either of the two. None of the Government Postgraduate Medical Institutes have any Research Cells or Departments. The National Institute of Preventive \& Social Medicine, the only Government Postgraduate Institute in the preventive sector, had its glorious past in making public health experts and researchers. But recently the institute has lost its name and fame. A number of postgraduate institutes in the Private Sector are currently offering Masters in Public Health, but only few of them making quality researchers to contribute to the health sector.

A large number of postgraduate students are enrolled every year in different postgraduate medical institutes of the country for higher education and as a part of the course curriculum they have to undertake a study which requires research 'know-how'. Given the above situation prevailing in the Tertiary Medical Institutes, it is quite unusual to expect that they will conduct research independently. They need training on different aspects of research methodology, like protocol writing, data analysis, statistical interpretation of data, report writing and so on. But there are limited scopes of learning on these topics in their respective institutes. Besides these, many beginners and young researchers seek formal training on 'Research Methodology' so that they can conduct study of their own.

In the context of the problem stated and scope prevailing, Planning and Research Department of 
DGHS, Dhaka could launch a formal Training Course on 'Research Methodology.' As a pilot testing 'Promoting Research in Health, Population \& Nutrition Sector for its Sustainable Development' could be started first in some Postgraduate Institutes and Medical Colleges and based on the success of this project, the programme could be gradually phased out in other Postgraduate Institutes and Medical Colleges. The project is expected to produce researchers and public health experts who could contribute to health development of the country, which in turn, would help people of our country to lead a socially and economically productive life.

\section{Reference :}

1. WHO Regional Publications Eastern Mediterranean Series 30, A Practical Guide for Health Researchers, Mahmoud F. Fathalla, World Health Organization, Regional Office for the Eastern Mediterranean Cairo, Egypt 2004.

2. Salam A. Notes on science, technology and science education in the development of the south. Prepared for the fifth meeting of the South Commission, May 27-30, 1989, Maputo, Mozambique. Trieste, The Third World Academy of Sciences.
3. Hwang S, Jiwon K. UN and SDGs: A Handbook for the Youths, 2016:1-74. Cited by 03-Jan-2020; Available at: ///C:/Users/HP/Downloads/UN and SDGs_A Handbook For Youth.pdf

4. Lennon S (nd). The Sustainable Development Goals and Australia - A National and Personal Roadmap to Sustainability. Cited by 02-Jan-2020; Available at: https://www.unaa.org.au/wp-content/uploads/2017/0 4/WA_UN_SDGsAndAustralia.pdf

5. UNDP. (2016). From the MDGs to Sustainable Development for All. Lessons of 15 Years of Practice. United Nations Development Programme, 92.

6. Rahdari A, Sepasi S, Moradi M. Achieving sustainability through Schumpeterian social entrepreneurship: The role of social enterprises. Journal of Cleaner Production 2016;137:347-360.

7. Boateng R, Heeks R, Molla A, Hinson R. E-commerce and Socio-Economic Development: Conceptualizing the Link. Internet Research 2008;18(5):562-592.

8. Fayomi OSI, Okokpujie IP, Udo Mfon. The Role of Research in Attaining Sustainable Development Goals. ICESW, IOP Publishing, IOP Conf. Series: Materials Science and Engineering . 2018;413:012002. doi:10.1088/1757-899X/413/1/012002 